Témoigner Témoigner. Entre histoire et mémoire

Getuigen Revue pluridisciplinaire de la Fondation Auschwitz

$118 \mid 2014$

Au nom des victimes. Dictature et terreur d'État en Argentine, Chili et Uruguay

\title{
On the circulation of swastikas
}

De la circulation des croix gammées

Overal hakenkruizen

Philippe Mesnard

\section{(2) OpenEdition \\ Journals}

\section{Electronic version}

URL: http://journals.openedition.org/temoigner/878

DOI: $10.4000 /$ temoigner.878

ISSN: 2506-6390

Publisher:

Éditions du Centre d'études et de documentation Mémoire d'Auschwitz, Éditions Kimé

Printed version

Date of publication: 1 October 2014

Number of pages: 6-7

ISBN: 978-2-84174-674-3

ISSN: 2031-4183

\section{Electronic reference}

Philippe Mesnard, « On the circulation of swastikas », Témoigner. Entre histoire et mémoire [Online], 118 | 2014, Online since 01 October 2015, connection on 23 October 2020. URL : http://

journals.openedition.org/temoigner/878; DOI : https://doi.org/10.4000/temoigner.878 


\section{ON THE CIRCULATION $0=S \vee \wedge A S T R A$} $\rightarrow$ By Philippe Mesnard,
Head of the Editorial Board

et us take advantage of the fact that four-monthly editorial is, by definition, no longe current news in order to express a few retrospective considerations. Less than a year ago, the Nazi swastika resurfaced in Putin's media to denounce what they called Ukrainians' Fascist downward spir an they called Ukrainians 'ascist downward spiral. An easily formerly was said, aimed to disqualify the separatis fornery was said, aimed to disqualify the separatist and pro-European orientations of the majority or the Viktor Ianouling brought about the deposition of ially warmongering positions of the new tsar.

Up to now, we agree, don't we? HOWEVER, TO ( ( pean news easily clained, is this not making Ukraine Wem - victim? Al! I can already her it sid that I crin - victin? Ah. I can already hear it said that I am exaggerating, hat I must not treat lightly the violent

Of course, this has never been my intention. Yet, on the other hand, as Perec used to say, facts do not peak for themselves. They were digested, on one in pring in presenting democratic transparency as its main Yet if the het, if the latter's stratagems are easy to detect, we can cirever whilst being surprised that Europe is turing a blind we to Uh anian extremism. $\mathrm{A}$ Europe, by the way, eye to where the last parliamentary elections revealed the wer of extreme-right politics. Something to meditate, isn't it?

But is the goal here to talk of Ukraine (target of Russian propaganda)? OR RATHER TO TALK OF TIE TIt In reality, both. The particular example serves as a way who is diffcult to circulate on this terrain where those whis are reognized as attackens-and who openly held this role - point to... truths nevertheless. It is on this point that I wish to more precisely express my opinion. a seme victim discourse, all form a same victim discourse, all formations and all groups as soon as they are the target of political violence. In this resect, the a itself - omnipre (or no to a itself - ommipresent, today, up to a point of saturathon -, as much as learning to grasp the complexity of the reality which information refers to, which at times is makine to from a distance all the while misleadingly

Of course mate

Of course, complexity is also a word that can be used to avoid saying anything. However, in the name of this complexity, we must also learn to suspend the victim and to better discen foct on the victim and to better discern what is being shown. It is thus inportant to remenber the permanence of Ukrainian ultranationalist ideas that still honour their pro-Nazi heroes guilty of anti-Semitic crimes, such as What is more, the latter wan to It is differt his statue being raised, nonetheless! In other words, it is not because Ukraine has claimed to be against Vladimir Putin's authoritative regime, that Ukrainian's main political tendencies are all unanimously close to democracy as it is conceived (imagined) within the European Community. Furthermore, forbidding the Russian language at the end of February 2014, formpower, hardly gave any power, hardy gave any guarantees of democracy. To tre not necessarily our friend.

THE EXPRESSION SEEMS TRITE, IT IS TRUE The problem - for it is important to maintain a conThe problem - for it is important to maintain a contradictory debate-, is that the down ward spirals of the entire society and not to believe in to disqualify the entire socity and not to believe in its potentia tory should be remembered. The history of a cour that war for remencer

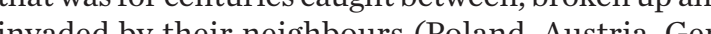
many, by their noviet Union). Renstia, Ger-

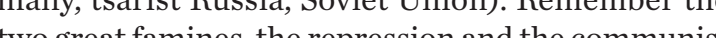
deportations during the 1930s and Serious disputes heavily Serous disputesheavily strained therelations between in this Bloodland until the begin. Civilwar can such brutality.

BRUTALITY, EXACTLY. At least, it was not directed anymore to the Jews, for in these lands, there directed anymore to the Jews, for in these lands, there decimation Jen with the pogroms dating frothe decination began with the pogroms dating from the 1914-1918 war, the 1920s and ending und rine 1914-1918 war, the 1920s and ending under the Nazi reign. In this sense, Putin's propaganda points to the truly sensitive zone of a country which, as well as all intic precisely leads us back to the swastika. (n)

Save the date

The French issue of the journa Testimony between history by Luba Jurgenson in the presence of Philippe Mesnard, at the Palabres meeting on 7 October 2014 at $7 \mathrm{pm}$ at the Hungarian Institu

Initiative: CIRCE (Centre Interdisciplinaire de Recherches Centre-Européennes), ParisSorbonne University and Adice (Association pour le Developpement des lintiatives

Organisation: Aurélie Rouget-Garma, Paris-Sorbonne University and CIRCE, Aurelie.Rouget-Garma@paris-sorbonne.fr

Coordination: Malgorzata Smorag-Goldberg, Paris-Sorbonne University and CIRCE maougocha@usa.net

www.facebook.com/Palabres

Indeed, when I saw the swastika being waved on television news, I immediately said to myself that thi cross is everywhere. We see it continually, alone or with Hitler's portrait. Also, it is not merely the question of the be place he ture. What is most worrisazis is the naturalizul f this syme of this symbol. Inmediately recognizable, simple, it badge or her with bad or a label. toy wor sulating hink of this idea?

To learn more about Ukrainian ultranationalism, its nostalgia and its (a) pogroms en Galicie, 194 in Luba Jurgenson \& Alexandre Prstojevic, Des Témoins aux heritiers
ins 